\title{
Optimal Manganese Nutrition Increases Photosynthesis of Immature Pecan Trees
}

\author{
Joshua Sherman ${ }^{1}$ \\ Department of Plant and Environmental Sciences, New Mexico State \\ University, MSC 3Q Box 30003, Las Cruces, NM 88003
}

\section{Richard J. Heerema}

Department of Plant and Environmental Sciences, New Mexico State University, MSC $3 Q$ Box 30003, Las Cruces, NM 88003; and Extension Plant Sciences Department, New Mexico State University, MSC 3Q Box 30003, Las Cruces, NM 88003

\section{Dawn VanLeeuwen \\ Economics, Applied Statistics, and International Business Department, New Mexico State University, MSC 3Q Box 30003, Las Cruces, NM 88003}

\section{Rolston St. Hilaire \\ Department of Plant and Environmental Sciences, New Mexico State University, MSC $3 Q$ Box 30003, Las Cruces, NM 88003}

Additional index words. Carya illinoinensis, carbon assimilation, nutrient deficiency, leaf manganese concentration, photosystem II, oxygen reaction center, water splitting complex, chlorophyll biosynthesis, stomatal conductance, intercellular $\mathrm{CO}_{2}$

\begin{abstract}
Southwestern U.S. pecan [Carya illinoinensis (Wangenh.) K. Koch] orchard soils are typically alkaline and calcareous, making micronutrients such as manganese (Mn) poorly available for root uptake. Manganese is essential to the light reactions of photosynthesis $\left(P_{n}\right)$, but the level of leaf $M n$ for optimum $P_{n}$ in pecan is unknown. Our objective was to characterize the relationships of foliar Mn fertilizer applications and leaf $M n$ nutrition with $P_{n}$ over a broad range of leaf Mn concentrations. Two experiments were conducted from 2011 to 2012 (Expt. 1) and in 2013 (Expt. 2) in immature, nonbearing 'Pawnee' and 'Western' pecan orchards near Las Cruces, NM. To create differential leaf tissue Mn concentrations, four Mn spray concentrations were applied foliarly: $0.00,0.34,0.68$, and $1.3 \mathrm{~g} \mathrm{Mn/L}$ (Control, Low, Medium, and High, respectively). In Expt. 2, we added a higher Mn concentration (2.7 g Mn/L). Repeated measurements of leaf $P_{n}$ were made beginning 1 week following a Mn application using a portable $P_{n}$ system. Across treatments in both studies, final leaf Mn concentrations ranged

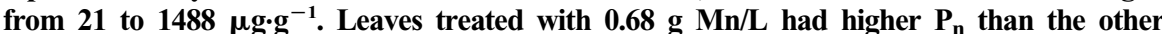
treatments in each experiment. In 2013, $P_{n}$ rates of the leaves treated with $0.68 \mathrm{~g} \mathrm{Mn} / \mathrm{L}$ increased $7.1 \%$ and $10.4 \%$ over the Control for 'Pawnee' and 'Western', respectively. Our data confirm an association between leaf tissue $M n$ and $P_{n}$; the leaf tissue $M n$ concentration at which $P_{n}$ rates are optimized in immature pecan trees was estimated to be $151.64( \pm 17.3 \mathrm{SE}) \mu \mathrm{g} \cdot \mathrm{g}^{-1} \mathrm{Mn}$.
\end{abstract}

Pecan (C. illinoinensis) is the only widely grown commercial nut tree species native to North America. The native distribution of

\footnotetext{
Received for publication 15 Aug. 2016. Accepted for publication 15 Nov. 2016

This project was made possible through Hatch funds, the New Mexico State University Agricultural Experiment Station, and Specialty Crops Research Initiative (SCRI-USDA-NIFA NO. 2010-01213) We thank the New Mexico State University Leyendecker Plant Science Research Center farm crew for assistance with maintaining the pecan orchards to the standards of the New Mexico pecan industry. We are also grateful to Marisa Potter, Sara Moran-Duran, and Barbara Hunter for help in collecting and processing data and leaf samples as well as applying foliar fertilizer.

${ }^{1}$ Corresponding author. E-mail: jdsherman@email. arizona.edu.
}

pecan is primarily along the Mississippi River Valley as far north as southeastern Iowa and south to Mississippi and Louisiana. Isolated populations of native pecans exist in Mexico, extending even as far south as Zaachila, Oaxaca, and Mexico (Janick and Paull, 2008; Thompson and Grauke, 1991). The native pecan region includes humid and semiarid areas with harsh to mild winters and annual rainfall between 660 and $1300 \mathrm{~mm}$ (Sparks, 2002, 2005).

In the southwestern United States, improved pecan cultivars have become a major driver for the agricultural economy with combined in-shell production value of $\$ 182$ million in 2014 for New Mexico and Arizona (USDA-NASS, 2015). One important way in which the growing environment in the southwestern pecan production region differs from that of the pecan native range and southeastern
U.S. growing areas is soil $\mathrm{pH}$. Southwestern pecan orchard soils typically have alkaline $\mathrm{pH}$ and are calcareous, whereas southeastern U.S. soils tend to be neutral to acidic (Chang, 1953; Worley, 1994). Plant available $\mathrm{Mn}$, more specifically $\mathrm{Mn}^{2+}$, and other micronutrients are less soluble and poorly available for root uptake by pecan trees in those alkaline soils (Chang, 1953; Lindsay, 1979; Sims, 1986; Sparks, 2000) and this results in micronutrient deficiency symptoms that are commonly visible in southwestern U.S. pecans orchards. The complexity of Mn availability in soil was suggested by Millaleo et al. (2010) and Rule and Graham (1976) who found soil Mn availability increased with high $\mathrm{pH}$ under white clover (Trifolium repens L.), but $\mathrm{Mn}$ availability decreased with higher $\mathrm{pH}$ under tall fescue (Festuca elatior L.), indicating that soil chemistry, plant species responses at the plant root to soil interface, and microorganism activity also may affect $\mathrm{Mn}$ availability (Barker and Pilbeam, 2015).

Zinc nutrition has been the subject of much intensive research in pecan since the early 1930s, when the "little leaf" and "rosette" symptoms were first identified as symptoms of zinc $(\mathrm{Zn})$ deficiency in pecan (Alben et al., 1932a, 1932b). Commercial pecan producers in the southwest today typically make multiple $\mathrm{Zn}$ fertilizer applications each growing season as part of their regular mineral nutrition programs (Heerema, 2013; Walworth and Pond, 2006). Manganese, on the other hand, has received relatively little attention from pecan researchers or growers, despite the roles it plays in plant carbon fixation.

Manganese is best known for its essential role in $\mathrm{P}_{\mathrm{n}}$, specifically on the oxidation side of the PS II complex in the oxygen reaction center, and as a coenzyme for biosynthesis of chlorophyll (Epstein and Bloom, 2005; Marschner, 1995). According to Kriedemann et al. (1985), inhibition of $P_{n}$ occurs in wheat even with moderate $\mathrm{Mn}$ deficiencies but chloroplast ultrastructure and chlorophyll breakdown (leading to visible symptoms of deficiency) occurs only with severe deficiencies. In the 1960s, Mn deficiency and its negative impact on $\mathrm{P}_{\mathrm{n}}$ was measured in spinach and tomato where there was a $50 \%$ to $70 \%$ reduction in photophosphorylation in isolated chloroplasts and rapid declines in Hill reaction activity (Spencer and Possingham, 1960, 1961).

Sufficient Mn concentration ranges in pecan leaflet tissue have been reported to be between 200-500 $\mu \mathrm{g} \cdot \mathrm{g}^{-1}$ (Jones et al.,1991) and 150-500 $\mu \mathrm{g} \cdot \mathrm{g}^{-1}$ (Robinson et al.,1997). Smith et al. (2001) published the first report of Mn deficiency in pecan. In their study, they showed that trees growing in a Texas soil with pH 7.2 had suppressed Mn uptake such that leaf concentrations were only 1 to 18 $\mu \mathrm{g} \cdot \mathrm{g}^{-1}$ and "shoot growth was short with pale green foliage but no discernible pattern of chlorosis." Foliar-applied Mn sulfate fertilizer increased leaf $\mathrm{Mn}$ concentrations to 
$138 \mu \mathrm{g} \cdot \mathrm{g}^{-1}$ and eliminated the chlorotic symptoms (Smith et al., 2001). Henriques (2003) showed that with decreasing $\mathrm{Mn}$ availability in field grown 'Kiowa' pecan trees, total chlorophyll content and $\mathrm{P}_{\mathrm{n}}$ rates decline dramatically, below $11 \mu \mathrm{g} \cdot \mathrm{g}^{-1} \mathrm{Mn}$ leaf tissue concentrations. In that study, without any Mn fertilizer applications, the "mildly deficient" plants (mean leaf Mn 11 $\mu \mathrm{g} \cdot \mathrm{g}^{-1}$ ) showed a $44.3 \%$ reduction of $\mathrm{P}_{\mathrm{n}}$ and the "severely deficient" plants (mean leaf Mn $7 \mu \mathrm{g} \cdot \mathrm{g}^{-1}$ ) showed a $62.9 \%$ reduction of $\mathrm{P}_{\mathrm{n}}$ when compared with plants with mean leaf Mn concentration of $79 \mu \mathrm{g} \cdot \mathrm{g}^{-1}$. In a second study, Henriques (2004) suggested that pecan adapt to Mn deficiency by reducing the chloroplast numbers while preserving PS II function in existing chloroplasts, which in turn reduces metabolic costs associated with low Mn concentrations. Other plant species form disorganized chloroplasts with low chlorophyll content, such as Spinacia oleracea and Senna obtusifolia (Homann, 1967).

Visible Mn toxicity is very rare in the southwestern United States, but NúñezMoreno (2009) reported reduced shoot growth and fruiting of 'Western' pecan in Arizona because of increased leaf Mn levels. Severely affected trees in that study had leaf Mn concentration of $4034 \mu \mathrm{g} \cdot \mathrm{g}^{-1}$, whereas unaffected trees had $1620 \mu \mathrm{g} \cdot \mathrm{g}^{-1}$ leaf Mn. Similarly, in a study involving potted 'Desirable' pecan trees, the toxic Mn levels in leaf tissue were $4525 \mu \mathrm{g} \cdot \mathrm{g}^{-1}$ (O'Barr et al., 1987). In Oklahoma, leaf Mn levels in 'Western' pecan trees have been reported as high as $2244 \mu \mathrm{g} \cdot \mathrm{g}^{-1}$ with no visible phytotoxicity symptoms (Smith and Cotton, 1985). Among other plant species, maize has a much lower tolerance to $\mathrm{Mn}$ toxicity with a critical threshold of only $200 \mu \mathrm{g} \cdot \mathrm{g}^{-1}$ resulting in leaf death (Marschner, 1995). Soybean has a threshold of up to $600 \mu \mathrm{g} \cdot \mathrm{g}^{-1}$, but sunflower can tolerate as high as $5300 \mu \mathrm{g} \cdot \mathrm{g}^{-1} \mathrm{Mn}$ in plant tissue before leaf tissue becomes chlorotic and eventually dies (Edwards and Asher, 1982; Marschner, 1995).

The NMSU Cooperative Extension Service recommends $100-300 \mu \mathrm{g} \cdot \mathrm{g}^{-1} \mathrm{Mn}$ in July sampled leaflet tissue for New Mexico pecan trees and University of Arizona Cooperative Extension recommends 104-674 $\mu \mathrm{g} \cdot \mathrm{g}^{-1}$ (Heerema, 2013; Walworth et al., 2011). New Mexico pecan orchards showed, on average, only $85 \mu \mathrm{g} \cdot \mathrm{g}^{-1} \mathrm{Mn}$ in leaf tissue (McCaslin and Boyse, 1999; Pond et al., 2006), but the level of $\mathrm{Mn}$ at which $\mathrm{P}_{\mathrm{n}}$ is optimum is not known. Symptoms of micronutrient deficient plants are not always visible even when the plant is deficient and this well-documented phenomenon is known as "hidden hunger" (Brady and Weil, 2007; Heerema, 2013). On a nutrient response curve, hidden hunger occurs when the concentration of the nutrient in the leaf is low enough to suppress plant performance (e.g., growth, yield) but not low enough for visible symptoms to be expressed.

The objective of our study was to investigate $P_{n}$ rates in relation to increasing $M n$ concentrations. To accomplish this, we characterized the effect of foliar Mn fertilizer applications on leaf $\mathrm{Mn}$ and $\mathrm{P}_{\mathrm{n}}$ and related physiological parameters over a broad range of leaf Mn concentrations.

\section{Materials and Methods}

Study site, experimental design, and treatments. Two experiments were conducted at the NMSU-Linwood Nursery Research Orchards at the Leyendecker Plant Science Research Center in Las Cruces, NM (lat. $32^{\circ} 11^{\prime} 39$ " N, long. 106 $44^{\prime} 18^{\prime \prime} \mathrm{W}$; elevation $1174 \mathrm{~m}$ ). The soils in the areas of the orchards used in the experiments are primarily Armijo clay loam (Aw; fine, smectitic, thermic Typic Torrerts), Harkey clay loam (Hk; coarse-silty, mixed, calcareous, thermic Typic Torrifluvents), Anapra clay loam (Ao; fine-silty over sandy or sandy-skeletal, mixed, superactive, calcareous, thermic Typic Torrifluvents), and Agua silt loam (Ag; coarse-loamy over sandy or sandyskeletal, mixed, superactive, calcareous, thermic Typic Torrifluvents). These soils are all characterized as having $\mathrm{pH}>7.5$ and good drainage, with a restrictive layer depth $>200$ $\mathrm{cm}$ (NRCS, 2014). The soils in the orchard were naturally stratified with $\mathrm{a} \approx 1 \mathrm{~m}$ layer of fine textured soils overlaying courser textured soils, but, before planting, the soil layers were mechanically mixed in the tree rows to a depth of $\approx 2-2.5 \mathrm{~m}$ for a more homogenous texture. Expt. 1 was conducted during the 2011 and 2012 growing seasons and Expt. 2 was conducted in the 2013 growing season. Twentyfour 'Pawnee' (on seedling 'VC1-68' rootstock) pecan trees planted in 2010 were used for Expt. 1. Trees were irrigated, pruned, and supplied other macro- and micronutrients according to standard cultural practices for the New Mexico pecan industry (New Mexico State University, 2016).

In Expt. 1, four treatments were assigned to trees (six single-tree replications per treatment) according to a completely randomized design. Treatments consisted of foliar applications of varying concentrations of amino acid chelate Mn fertilizer (Manganese Metalosate ${ }^{\circledR}$; Albion Plant Nutrition, Clearfield, UT) solution. Increasing applications per concentration rate of $\mathrm{Mn}$ was to create greater differences between Mn treatments. Expt. 1 treatments were as follows:

1) High: $1.3 \mathrm{~g} \mathrm{Mn} / \mathrm{L}$; applied three times in 2011 (25 May, 8 June, and 22 June) and five times in 2012 (25 May, 8 June, 24 June, 14 July, and 27 July).

2) Medium: $0.68 \mathrm{~g} \mathrm{Mn} / \mathrm{L}$; applied two times in 2011 (25 May and 8 June) and four times in 2012 (25 May, 8 June, 24 June, and 14 July).

3) Low: $0.34 \mathrm{~g} \mathrm{Mn} / \mathrm{L}$; applied one time in 2011 (25 May) and three times in 2012 ( 25 May, 8 June, and 24 June).

4) Control: 0.00 g $\mathrm{Mn} / \mathrm{L}\left(\mathrm{H}_{2} \mathrm{O}\right.$ only); applied three times in 2011 (25 May, 8 June, and 22 June) and five times in 2012 (25 May, 8 June, 24 June, 14 July, and 27 July).

Expt. 2 was conducted in 2013 and consisted of 30 'Pawnee' (planted in 2010) and 30 'Western' cultivar (syn. 'Western Schley'; planted in 2011) pecan trees. Trees were irrigated, pruned, and supplied other macroand micronutrients using standard cultural practices for the New Mexico pecan industry. Five treatments were assigned to trees (six single-tree replications per cultivar and treatment) according to a completely randomized design; however, blocks were formed based on measurement sequence. Thus, using blocks based on measurement time accounted for environmental factors which are variable throughout the morning. Five Mn treatments were applied to both cultivars on the same dates and the concentrations are as follows (the same Mn fertilizer was used as in Expt. 1):

1) Ultra High: $2.7 \mathrm{~g} \mathrm{Mn} / \mathrm{L}$; applied six times (4 June, 19 June, 4 July, 20 July, 8 Aug., and 21 Aug.)

2) High: $1.3 \mathrm{~g} \mathrm{Mn} / \mathrm{L}$; applied five times (4 June, 19 June, 4 July, 20 July, and 8 Aug.).

3) Medium: $0.68 \mathrm{~g} \mathrm{Mn} / \mathrm{L}$; applied four times (4 June, 19 June, 4 July, and 20 July).

4) Low: $0.34 \mathrm{~g} \mathrm{Mn} / \mathrm{L}$; applied three times (4 June, 19 June, and 4 July).

5) Control: $0.00 \mathrm{~g} \mathrm{Mn} / \mathrm{L}\left(\mathrm{H}_{2} \mathrm{O}\right.$ only); applied six times (4 June, 19 June, 4 July, 20 July, 8 Aug., and 21 Aug.).

Leaf gas exchange. Leaf gas exchange [including $\mathrm{P}_{\mathrm{n}}$, stomatal conductance $\left(g_{\mathrm{S}}\right)$, intercellular $\mathrm{CO}_{2}\left(c_{\mathrm{i}}\right)$ ] and photosynthetic active radiation $(P A R)$ were measured using the LI$6400 X T$ portable $P_{n}$ system equipped with the 6400-02B Red/Blue Light Source (LI-COR Biosciences, Lincoln, NE) 1 week after every Mn application when possible for repeated measurements throughout the season. Except on the initial measurement date, gas exchange measurements were sequenced to ensure that each treatment's measurements were spaced throughout the morning.

Fully sun-exposed lateral leaflets of leaves located midway between the shoot apex and the transition of current-season to previousseason shoot growth were used for gas exchange measurements. On the south side of each tree, gas exchange measurements were made between 0800 and 1300 HR with light intensity set to "track $P A R$ " so that the leaflet in the chamber was exposed to the same irradiance as the leaflet was receiving just before measurement. On days where scattered, thin clouds had potential to shade sunlight, $P A R$ was set for constant $1700 \mu \mathrm{mol} \mathrm{m}{ }^{-2} \cdot \mathrm{s}^{-1}$. In Expt. 2, time clusters were created as a blocking factor and $P A R$-in was adjusted between replications on each measurement date to account for the variability of ambient $P A R$ measurement. Lombardini et al. (2009) and Anderson (1994) reported light saturation for pecan $\mathrm{P}_{\mathrm{n}}$ at $1500-1700 \mu \mathrm{mol} \cdot \mathrm{m}^{-2} \cdot \mathrm{s}^{-1}$. Average $P A R$ in Expt. 1 was $1986 \mu \mathrm{mol} \cdot \mathrm{m}^{-2} \cdot \mathrm{s}^{-1}$ and in Expt. 2 was $1821 \mu \mathrm{mol} \cdot \mathrm{m}^{-2} \cdot \mathrm{s}^{-1}$. Carbon dioxide $\left(\mathrm{CO}_{2}\right)$ concentration (reference $\left.\mathrm{CO}_{2}\right)$ was held constant in the chamber at 390 $\mu \mathrm{L} \cdot \mathrm{L}^{-1}$, near ambient atmospheric $\mathrm{CO}_{2}$ levels.

In both experiments, midday stem water potential $\left(\Psi_{\text {swp }}\right)$ was measured from one 
completely shaded fully expanded leaf (sealed in a reflective plastic bag for $\approx 20$ $40 \mathrm{~min}$ ) from each experimental tree on the same dates as gas exchange was measured using the Scholander pressure chamber (PMS Instrument Company, Albany, OR) to determine plant moisture stress levels, since $P_{n}$ is negatively impacted when tree water potential is less than $-0.9 \mathrm{MPa}$ (Othman et al., 2014). In Expt. 1, on every date $\Psi_{\text {swp }}$ was -0.9 or higher with the exception for one tree on 18 June 2012, six trees on 29 June 2012, and four trees on 20 July 2012; however, on none of these did $\Psi_{\text {swp }}$ measure lower than -1.0 MPa. In Expt. 2, there was one tree on 13 June 2013 that measured no lower than $-1.02 \mathrm{MPa} \Psi_{\text {swp }}$ and on 27 June 2012 two trees measured no lower than $-1.0 \mathrm{MPa}$ for $\Psi_{\text {swp. }}$. For the cultivar Pawnee in Expt. 2, on no dates did any tree have $\Psi_{\text {swp }}$ go lower than $-0.9 \mathrm{MPa}$.

Chlorophyll. In both experiments, a portable chlorophyll meter [Soil Plant Analytical Development (SPAD)] (SPAD 502; Konica Minolta, Ramsey, NJ) was used to measure greenness of the interveinal regions of the same leaflets measured for $\mathrm{P}_{\mathrm{n}}$.

Leaf tissue chlorophyll content was measured in Expt. 2 at the end of the growing season and after all applications of Mn had been administered (20 Sept.). The leaflet was chosen using the same protocol for leaf sampling. On the same day, $\approx 50 \mathrm{mg}$ of fresh weight (FW) of leaf from $28.27-\mathrm{mm}^{2}$ discs were taken from the interveinal regions of leaflets. Leaf tissue discs were stored at $-80^{\circ} \mathrm{C}$ before grinding with a mortar and pestle in $\approx 2 \mathrm{~mL}$ liquid nitrogen. The $50 \mathrm{mg}$ ground samples were each placed in $10 \mathrm{~mL}$ of $99.6 \%$ acetone and centrifuged at $2700 g_{\mathrm{n}}$ for $10 \mathrm{~min}$. Absorbance of the supernatant was made at 662,645 , and $470 \mathrm{~nm}$ using a SpectraMax M2 spectrophotometer running SoftMax Pro, version 5 software (Molecular Devices LLC, Sunnyvale, CA). Tissue chlorophyll a, chlorophyll $\mathrm{b}$, chlorophyll $\mathrm{a}+\mathrm{b}$, and carotenoid contents were calculated using the equations of Lichtenthaler and Wellburn (1983) and Zhang et al. (2005) as follows:

$$
\begin{aligned}
\text { Chl a }= & (11.24 \times \text { absorbance at } 662 \mathrm{~nm}) \\
& -(2.04 \times \text { absorbance at } 645 \mathrm{~nm}) \\
\text { Chl b }= & (20.13 \times \text { absorbance at } 645 \mathrm{~nm}) \\
& -(4.19 \times \text { absorbance at } 662 \mathrm{~nm})
\end{aligned}
$$

Chl a $+\mathrm{b}=(7.05 \times$ absorbance at $662 \mathrm{~nm})$

$$
+(18.09 \times \text { absorbance at } 645 \mathrm{~nm})
$$

Carotenoids(xanthophylls and beta - carotene)

$$
\begin{aligned}
= & {[(1000 \times \text { absorbance at } 470 \mathrm{~nm})} \\
& -(1.90 \times \mathrm{Chl} \mathrm{a}-63.14 \times \mathrm{Chl} b)] \div 214
\end{aligned}
$$

Leaflet tissue nutrient analyses. Leaflet tissue samples were collected from 12 nonfruiting shoots per tree on 25 July 2011, 25 Aug. 2012, and on 24 Aug. 2013 (after foliar Mn applications were completed), according to the method described by Heerema
(2013). Leaflet tissue samples were also collected on 24 May 2012 (before any 2012 foliar Mn applications) in Expt. 1 to determine if there were any carryover effects from $2011 \mathrm{Mn}$ applications. Leaflet samples were washed briefly in a phosphorous-free detergent bath, rinsed once with deionized water, washed in a $0.1 \mathrm{~m}$ hydrochloric acid bath, and then rinsed twice with deionized water. Samples were dried at $60^{\circ} \mathrm{C}$ for $48 \mathrm{~h}$ in paper bags. In 2011 and 2013, nutrient analyses were performed using the methods developed by Gavlak et al. (1994) for determining macro- and micronutrients, Jones et al. (1991) for protocol on microwave digestion, and U.S. Environmental Protection Agency (1982) Staff for determination of trace elements using a Perkin Elmer Optima 4300 DV Inductively Coupled Plasma/ Optical Emission Spectrometer (PerkinElmer, Waltham, MA). Total Kjeldahl nitrogen (TKN) was determined using a Technicon AutoAnalyzer (SEAL Analytical, Southampton, UK). In 2012, leaf analyses were performed using the methods developed by Gavlak et al. (1994) for determining macroand micronutrients using a Perkin Elmer 5300 Inductively Coupled Plasma/Atomic Emissions Spectroscopy (PerkinElmer) and TKN using a LECO 528 (LECO, St. Joseph, MI).

Statistical analyses. For all statistical analyses, sensitivity of findings to extreme data points was examined using the outlier strategy with outliers identified as those observations with studentized residual magnitude $>2.5$ (Ramsey and Schafer, 2002).
Statistical significance was defined as $P \leq$ 0.05 and Fisher's protected least squares difference was used to compare the magnitude of difference between treatments and protect the experiment-wise error. SAS software, version 9.3 (SAS Institute Inc., Cary, NC, 2010) was used for all analyses.

Leaf Mn concentrations were analyzed separately by year (Expt. 1) and cultivar (Expt. 2) with Mn treatment as the explanatory variable using a mixed model that fit separate treatment group variances to account for increasing variance.

Gas exchange data $\left(\mathrm{P}_{\mathrm{n}}, g_{\mathrm{S}}\right.$, and $\left.c_{\mathrm{i}}\right)$ and SPAD for Expt. 1 were analyzed with years 2011 and 2012 combined as a completely randomized design with repeated measures. The mixed model included fixed effects for treatment, date, and their interaction. A heterogeneous compound symmetric variance structure was fitted to the repeated measures. For Expt. 2, the datasets for 'Pawnee' and 'Western' cultivars were analyzed separately as randomized complete block designs with repeated measures. Random effects for block and block by date were added to the model used for Expt.1.

Chlorophyll content was analyzed as a two-way factorial with Mn treatment and cultivar as factors.

$\mathrm{P}_{\mathrm{n}}$ data collected on the date closest to leaflet sampling in each season from Expts. 1 and 2 were combined to characterize the relationship between leaf $\mathrm{Mn}$ concentration and the $P_{n}$ rate. Both mixed model regressions of $\mathrm{P}_{\mathrm{n}}$ on polynomial functions of leaf $\mathrm{Mn}$ and

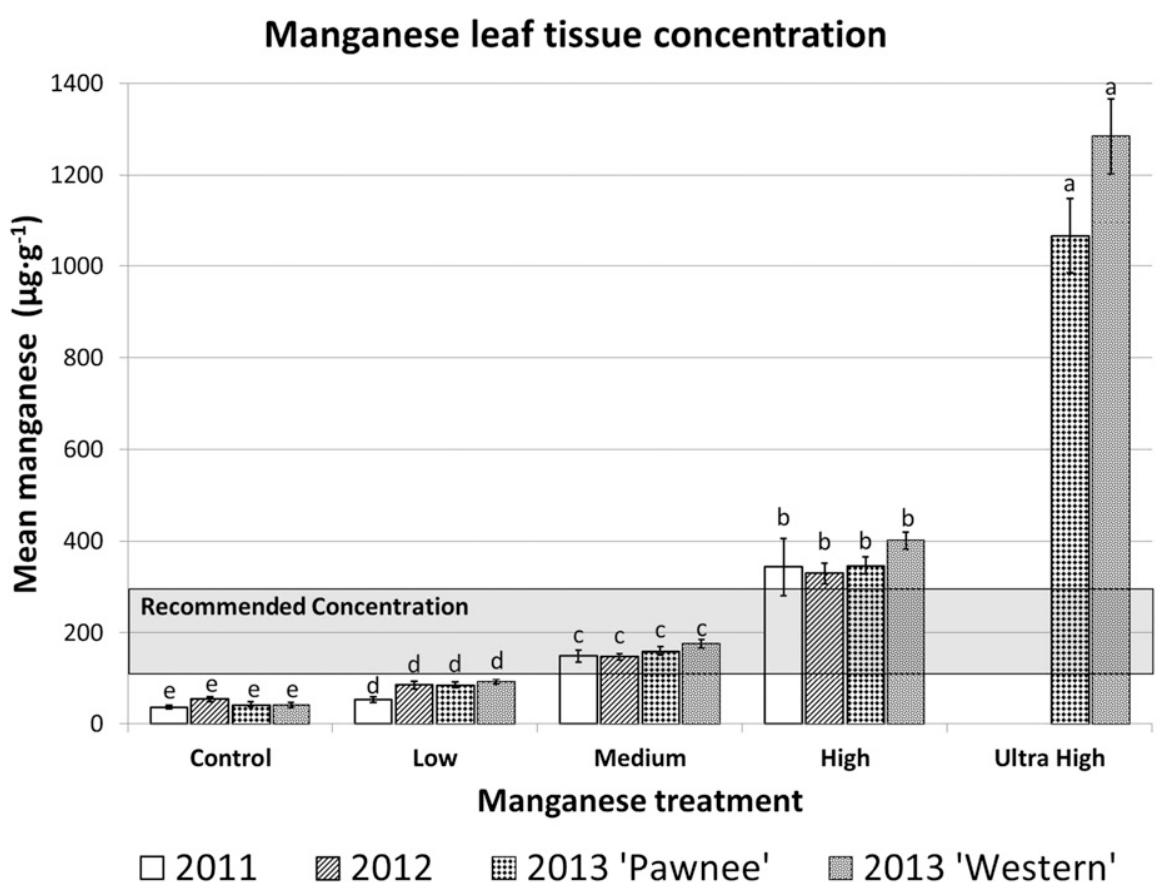

Fig. 1. Leaf manganese (Mn) concentrations per dry weight of tissue in 2011, 2012, and 2013 showing treatment application effect of the Control, Low, Medium, High, and Ultra-High treatments in 'Pawnee' and 'Western' pecan cultivars. Data are least squares means and bars correspond to the model-based standard error. New Mexico Cooperative Extension recommendation of leaf Mn concentration is shown in gray shaded region. Within year and cultivar, leaf Mn concentration means not accompanied by the same lower case letter are significantly different $(P \leq 0.05)$. 
design-based analyses using a four-level factor corresponding to combinations of year and cultivar, the treatment factor, and random blocks corresponding to measurement clusters. Because the Ultra-High treatment level was added in Expt. 2, a generalization of the methods of Piepho et al. (2006) was used to account for the missing cells and explicitly accommodate the $4 \times 4+2$ treatment structure by creating a three-level variable with one level corresponding to the $4 \times 4$ factorial portion of the design, another level for the Ultra-High-treated 'Western' cultivar and the third level for the Ultra-High-treated 'Pawnee' cultivar. For leaf Mn, separate variances were fit to each treatment group. For $\mathrm{P}_{\mathrm{n}}, \mathrm{Mn}$ treatment means $( \pm \mathrm{SE})$ were reported and formally compared. If the interaction test or the test comparing 'Western' and 'Pawnee' cultivars at the Ultra-High treatment level was significant then this was noted.

The mixed model polynomial regressions used only data corresponding to leaf Mn values below 500 units (Mn range 21.25-472.2 $\mu \mathrm{g} \cdot \mathrm{g}^{-1}$ ) (i.e., data from the Ultra-High treatment group were removed). Initial models included leaf Mn polynomial terms up to and including the cubic term, the year-cultivar factor, the year-cultivar by polynomial term interactions, and a random effect for measurement cluster block within year and cultivar. A reduced model was obtained using Type I (sequential) hypotheses to eliminate insignificant terms. The final model included separate cultivar intercepts and a cubic polynomial but no interactions. The leaf $\mathrm{Mn}$ value corresponding to optimal $P_{n}$ was estimated by taking the derivative of the cubic polynomial, then applying the quadratic formula to find the root of the derivative corresponding to the maximum. The standard error of the estimated optimal leaf Mn was obtained using the delta method (Casella and Berger, 2002). Scale-related numeric problems were resolved by dividing the leaf Mn concentrations by 100 .

\section{Results and Discussion}

Leaflet tissue Mn and chlorophyll concentrations. Average leaf Mn concentrations for the Medium Mn treatment in all years and both cultivars were consistently within the normal/recommended range of $100-300 \mu \mathrm{g} \cdot \mathrm{g}^{-1}$ (mean range of 147-176 $\mu \mathrm{g} \cdot \mathrm{g}^{-1}$; Fig. 1). Leaf tissue Mn concentration in the Control trees in both experiments was well below the normal/recommended range. In Expt. 2, the Ultra-High Mn treatment had average leaf $\mathrm{Mn}$ concentrations between 1000 and $1300 \mu \mathrm{g} \cdot \mathrm{g}^{-1}$ (Fig. 1) with no visible signs of toxicity. These Mn concentrations indicate that $\mathrm{Mn}$ treatments created a broad range of leaf $\mathrm{Mn}$ concentrations for observing differences in $\mathrm{P}_{\mathrm{n}}$ and other physiological parameters. For all treatments, average leaf concentration of other macro- and micronutrients were within the recommended/ normal ranges of Heerema (2013) in both experiments (data not presented).
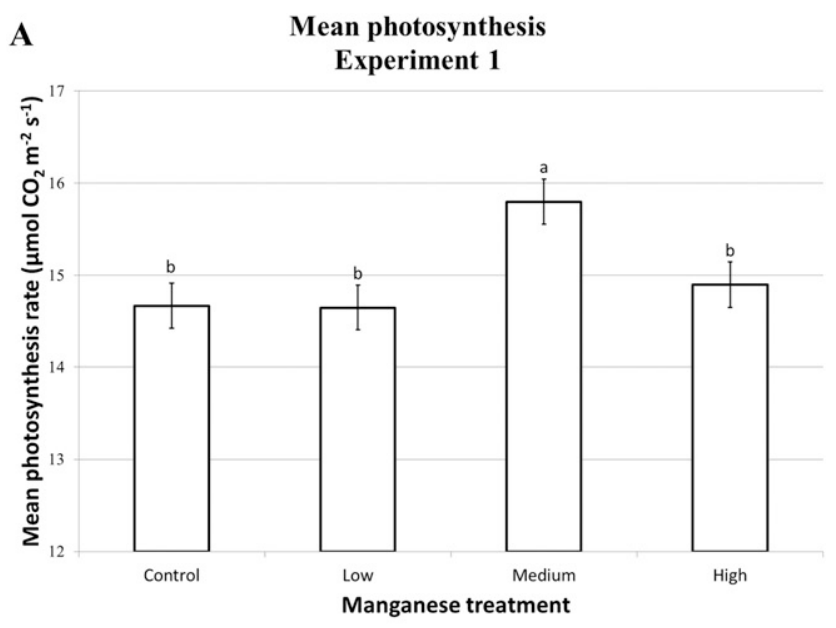

B Intercellular $\mathrm{CO}_{2}$
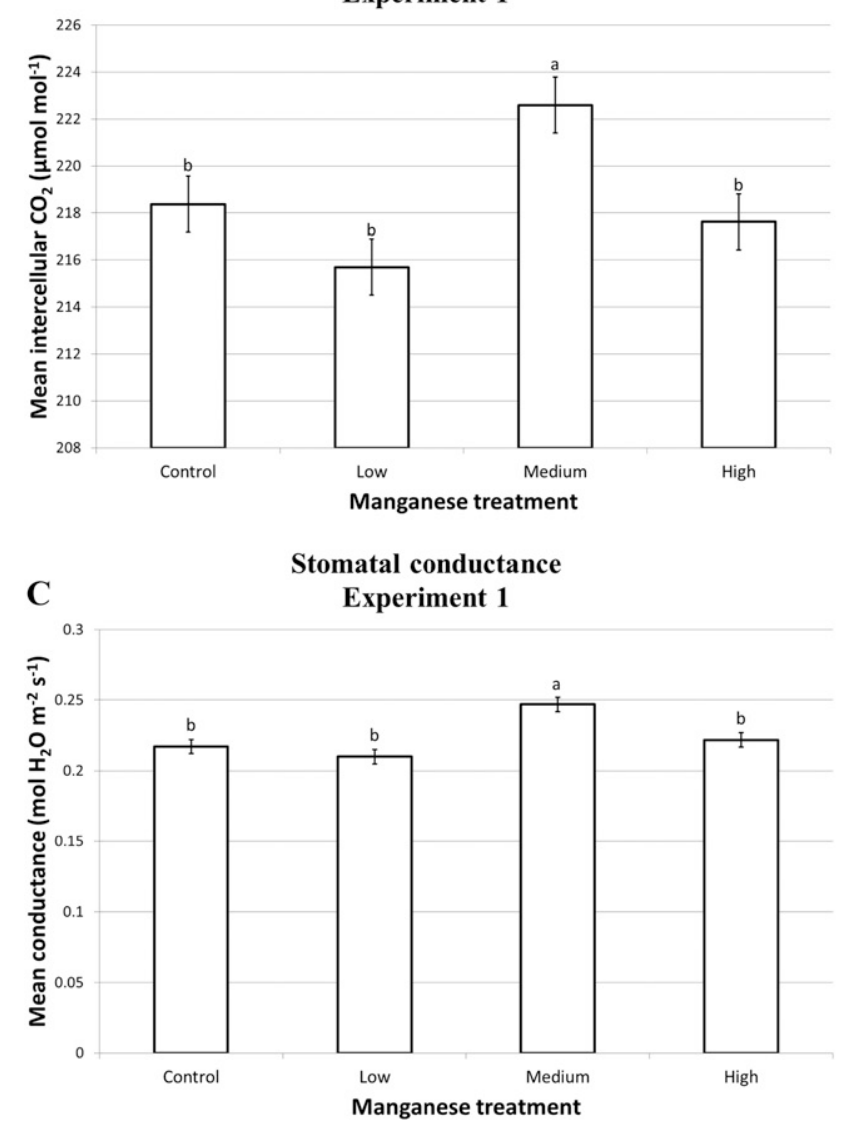

Fig. 2. Mean (A) leaflet photosynthesis, (B) intercellular $\mathrm{CO}_{2}$, and (C) stomatal conductance, respectively, on cultivar Pawnee across the season in Expt. 1. A total of three measurement dates in 2011 and five dates in 2012. Foliar applied manganese (Mn) treatments ranged from 0.0 to $1.3 \mathrm{~g} \mathrm{Mn} / \mathrm{L}$. Data are least squares means and bars correspond to the model-based standard error. Means not accompanied by the same lower case letter are significantly different $(P \leq 0.05)$.

Leaf Mn concentrations were not significantly different across treatments on May 2012 (before $2012 \mathrm{Mn}$ applications), suggesting little to no carryover in the trees of remobilized leaf Mn from 2011 (data not shown). If Mn carried over from the previous season comprised an appreciable part of leaf $\mathrm{Mn}$ in May 2012, we would expect to see some similar pattern of differential leaf $\mathrm{Mn}$ concentrations among the treatments early in
2012 before Mn applications had begun in that season.

Even at Mn concentrations as low as $24 \mu \mathrm{g} \cdot \mathrm{g}^{-1}$ in the Control, which is well below the level considered deficient for $\mathrm{Mn}$ in pecan, no visible signs of $\mathrm{Mn}$ deficiency such as interveinal chlorosis were noted at any point during the experiments. There were no significant differences for SPAD $(P \leq 0.05)$ among treatments in Expt. 1 or 2 (data not shown). The 
SPAD (or greenness) means across Mn treatments in Expt. 1 ranged from 41.9 to 42.6 and in Expt. 2 ranged from 43.9 to 45.8 for 'Pawnee' and 40.1 to 41.9 for 'Western'.

There were no statistically significant differences $(P \leq 0.05)$ for total chlorophyll content measured in Expt. 2 (data not shown). Total chlorophyll $(\mathrm{a}+\mathrm{b})$ means ranged from 8.3 to $10.2 \mu \mathrm{g} \cdot \mathrm{g}^{-1} \mathrm{FW}$ for the 'Pawnee' and 5.7-7.2 $\mu \mathrm{g} \cdot \mathrm{g}^{-1} \mathrm{FW}$ for the 'Western'. Chlorophyll a/b ratio means ranged from 2.0 to 2.1 for both cultivars.

Gas exchange. The Mn treatment main effect on $\mathrm{P}_{\mathrm{n}}$ was significant in both experiments. Specifically, across dates, the Medium $\mathrm{Mn}$ treatment had significantly higher $\mathrm{P}_{\mathrm{n}}$ than the other treatments (Figs. 2A and 3A). In both experiments, the date effect was also significant for these gas exchange parameters, but the interaction between treatment and date was not significant. The percentage increase in $P_{n}$ between the Medium Mn treatment and the Control was $7.1 \%$ in Expt. 1. In Expt. 2, the $P_{n}$ rate increase between the Medium and Control treatments was $6.5 \%$ and $8.6 \%$ for the 'Pawnee' and 'Western' cultivars, respectively. In Expt. 1, $\mathrm{P}_{\mathrm{n}}$ for the Low and High treatments were not significantly different from the Control. In Expt. 2, however, the High and Ultra-High treatments were significantly lower in $\mathrm{P}_{\mathrm{n}}$ than the Control in both cultivars. Henriques (2003) research indicated significant decrease in $P_{n}$ as $\mathrm{Mn}$ in leaf tissue became more deficient $(<11$ $\left.\mu \mathrm{g} \cdot \mathrm{g}^{-1}\right)$ and severe enough to produce visible symptoms. Our results indicate that even with slight deficiencies in $\mathrm{Mn}$ (not yet inducing visible symptoms), $P_{n}$ is negatively impacted. We speculate that with optimum level of Mn in the medium treatment there is higher electron transport rates, light reactions, and $\mathrm{NADPH}$ turnover for the dark reactions, therefore, increased assimilation of $\mathrm{CO}_{2}$.

Intercellular $\mathrm{CO}_{2}$ did not consistently show significant differences among the $\mathrm{Mn}$ treatments during the two experiments. In Expt. 1, the Medium Mn treatment had higher $c_{\mathrm{i}}$ than the other treatments (Fig. 2B). For Expt. 2, however, the $c_{\mathrm{i}}$ did not show any treatment effect differences for the 'Pawnee' and 'Western' (data not shown) despite increased $g_{\mathrm{S}}$. Means of $c_{\mathrm{i}}$ in the 'Pawnee' and 'Western' cultivar in Expt. 2 ranged from 243 to $250 \mu \mathrm{mol} \mathrm{mol}^{-1}$.

$g_{\mathrm{S}}$ followed a similar pattern to that of $\mathrm{P}_{\mathrm{n}}$, with the Medium Mn treatment having significantly higher $g_{\mathrm{S}}\left(250 \mathrm{~mol} \mathrm{H}_{2} \mathrm{O} \mathrm{m} \mathrm{m}^{-2} \cdot \mathrm{s}^{-1}\right)$ than all other treatments in Expt. 1 (Fig. 2C). In Expt. 2, $g_{\mathrm{S}}$ for the Medium Mn treatment was higher than all other treatments in the 'Western' but not different from the low Mn treatment in the 'Pawnee' (Fig. 3B). The percent increase of $g_{\mathrm{S}}$ between the Medium Mn treatment and Control was 12\% in Expt. 1. In Expt. 2, percentage increase in $g_{\mathrm{S}}$ between the Medium and Control treatments was $13.8 \%$ for the 'Western' and $8.6 \%$ for the 'Pawnee'. In Expt. 2, the mean $g_{\mathrm{S}}$ for the Medium Mn treatment in 'Pawnee' and 'Western' was 350 and $360 \mathrm{~mol} \mathrm{H}_{2} \mathrm{O} \mathrm{m}{ }^{-2} \cdot \mathrm{s}^{-1}$, respectively (Fig. 3B). In Expt. 1, $g_{\mathrm{S}}$ for the Low

A

\section{Mean photosynthesis \\ Experiment 2}

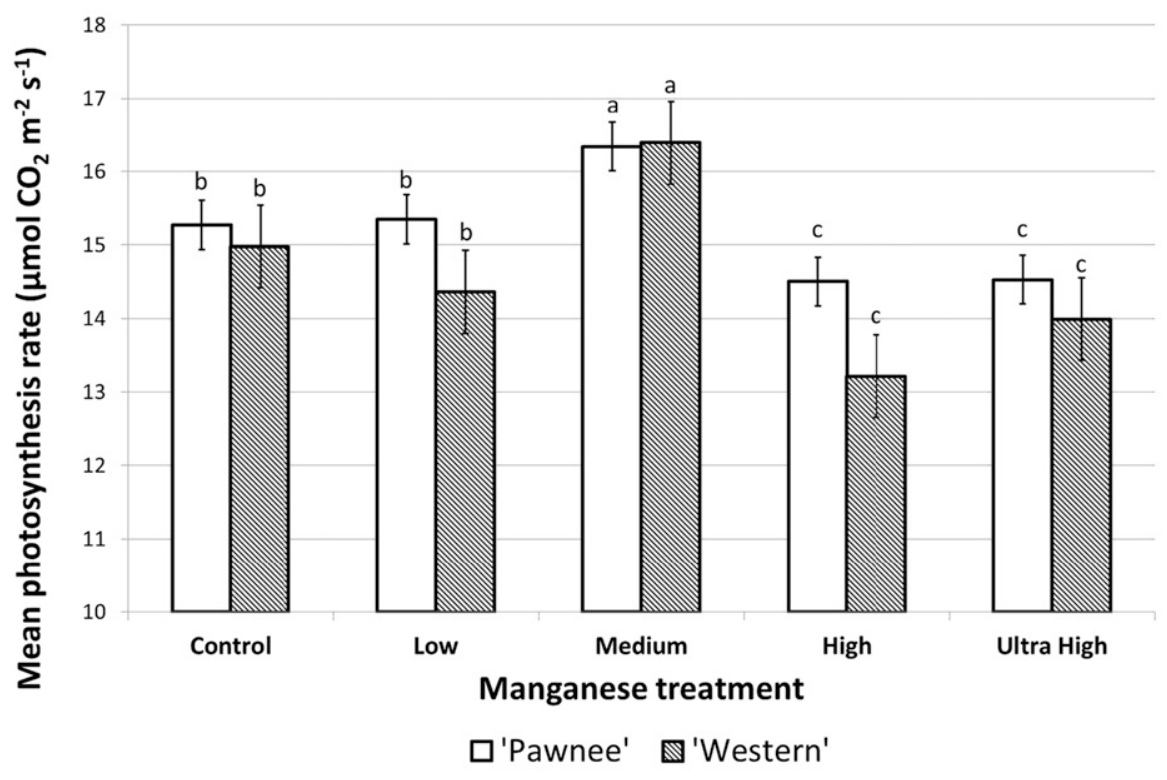

B Stomatal conductance

Experiment 2

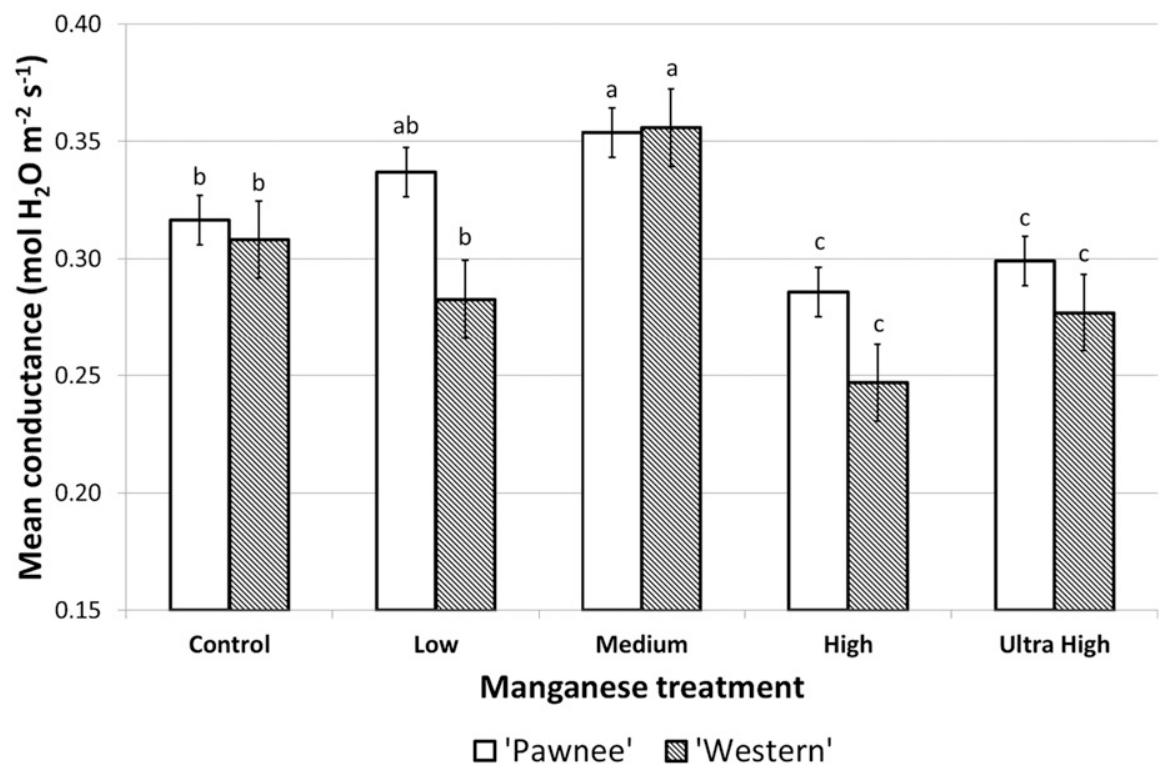

Fig. 3. Mean (A) leaflet photosynthesis and (B) stomatal conductance, respectively, on 'Pawnee' and 'Western' pecans across the season in Expt. 2. Six measurement dates total of each cultivar. Foliar applied manganese (Mn) treatments ranged from 0.0 to $2.7 \mathrm{~g} \mathrm{Mn} / \mathrm{L}$. Data are least square means and bars correspond to the model-based standard error. Within cultivar, means not accompanied by the same lower case letter are significantly different $(P \leq 0.05)$.

and High treatments were not significantly different from the Control; however, in Expt. 2, the High and Ultra-High treatments showed significantly lower $g_{\mathrm{S}}$ than the Control.

Similarly, Henriques (2003) showed a pattern of increasing $g_{\mathrm{S}}$ with increasing leaf $\mathrm{Mn}$ concentration when leaf Mn was below 100 ppm. Furthermore, in our study, $g_{\mathrm{S}}$ was lower for the High and Ultra-High Mn treatments, where mean leaf $\mathrm{Mn}$ exceeded $300 \mu \mathrm{g} \cdot \mathrm{g}^{-1}$, than in the Medium Mn treatment where leaf Mn values were between 149-176 $\mu \mathrm{g} \cdot \mathrm{g}^{-1}$.
This suggests that stomata of pecan respond to increased demand for $\mathrm{CO}_{2}$ in the leaves of trees with optimal Mn levels. However, in agreement with Henriques (2003), interpretation of the relationship between $\mathrm{CO}_{2}$ uptake, $g_{\mathrm{S}}$, and $c_{\mathrm{i}}$ is difficult since they vary with internal and environmental conditions. In addition to stomatal responses to light intensity and quality, leaf water status, mesophyll metabolites (i.e., ABA), root metabolites (i.e., cytokinins), salinity, and humidity, $g_{S}$ can be affected by intercellular and boundary 


\section{Photosynthesis to manganese relationship cubic polynomial}

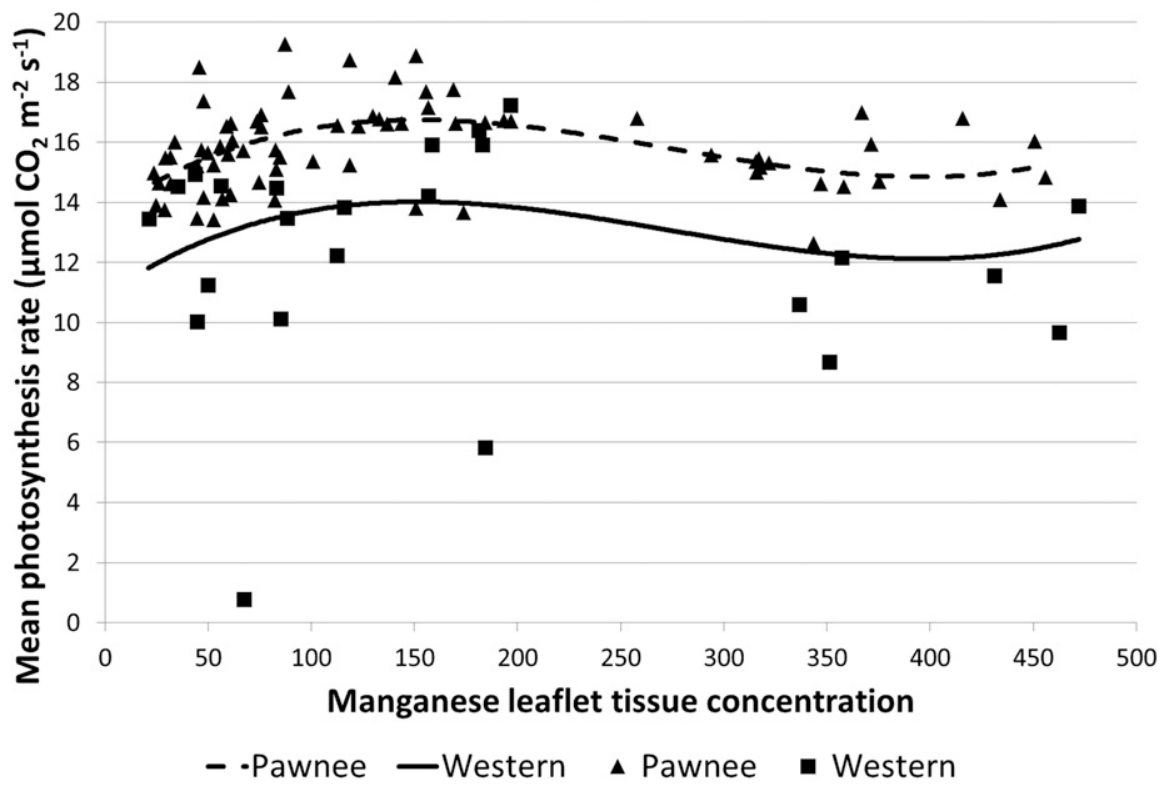

Fig. 4. Relationship of photosynthesis rate of leaflets to leaf tissue manganese (Mn) concentration by dry weight. Leaf tissue sampled 1 week following photosynthesis measurements. The data from both experiments were fitted to the cubic polynomial equation $y=4.6546(\mathrm{Mn} / 100)-2.1219(\mathrm{Mn} / 100)^{2}+$ $0.2581(\mathrm{Mn} / 100)^{3}$ with $y$ intercepts 13.66 for 'Pawnee' and 10.94 for 'Western'. Significance level set at $P \leq 0.05$

layer $\mathrm{CO}_{2}$ concentrations (Farquhar and Sharkey, 1982). It is not conclusive, however, that $\mathrm{Mn}$ deficiency affects stomatal limitation to net $\mathrm{P}_{\mathrm{n}}$ as confirmed in previous studies on other plant species (Henriques, 2003; Ohki, 1985; Terry and Ulrich, 1974; Weiland et al., 1975). For example, Terry and Ulrich (1974) indicated findings in beet where even though $\mathrm{P}_{\mathrm{n}}$ declined by one-third in Mn-deficient leaves compared with control the stomatal openings remained unchanged. Weiland et al. (1975) further observed in soybean a $50 \%$ reduction in $\mathrm{P}_{\mathrm{n}}$ of $\mathrm{Mn}$-deficient third and fourth leaf nodes and $70 \%$ reduction in $\mathrm{P}_{\mathrm{n}}$ in the fifth node but no difference in stomatal aperture or size compared with controls under microscopic examination. It may be that the leaf stomatal response in trees with optimal Mn (and therefore greater leaf photosynthetic capacity) would allow increased transfer of $\mathrm{CO}_{2}$ from the atmosphere into the leaf intercellular spaces to better supply the additional demands for $\mathrm{CO}_{2}$ by the Calvin cycle and, furthermore, mitigate photorespiration.

Leaflet Mn to Pn relationship. The designbased analysis using the $\mathrm{P}_{\mathrm{n}}$ sampling closest to the leaflet sampling date did not detect a Mn treatment by cultivar-year combination interaction $(P=0.5706)$ but did detect both Mn treatment and cultivaryear main effects $(P=0.0066$ and $<0.0001$, respectively). $\mathrm{P}_{\mathrm{n}}$ was higher for the Medium $\mathrm{Mn}$ treatment $\left[16.17( \pm 0.41) \mu \mathrm{mol} \mathrm{CO}_{2}\right.$ $\left.\mathrm{m}^{-2} \cdot \mathrm{s}^{-1}\right]$ than for the Control, Low, High, or Ultra-High Mn treatments [14.84 $( \pm 0.41)$, $14.42( \pm 0.41), 14.28( \pm 0.41)$, and 13.51 $( \pm 0.58) \mu \mathrm{mol} \quad \mathrm{CO}_{2} \mathrm{~m}^{-2} \cdot \mathrm{s}^{-1}$, respectively].
Although reanalysis with two outliers removed detected a significant interaction, overall means were changed little with estimates for the Low and Medium treatments increasing by 0.5 and $0.45 \mu \mathrm{mol} \mathrm{CO}_{2}$ $\mathrm{m}^{-2} \cdot \mathrm{s}^{-1}$, respectively. The reanalysis reduced variance estimates, however, and as a result the Ultra-High $P_{n}$ estimate was found to be significantly lower than the Control, Low, and Medium Mn treatment $\mathrm{P}_{\mathrm{n}}$ estimates. Consistent with analyses using the data from all sampling dates, within each cultivar-year combination, the $\mathrm{Me}$ dium $\mathrm{Mn}$ treatment had the numerically highest estimated $P_{n}$.

Leaf tissue Mn concentration was different between the treatments and findings from the design-based analysis combining data from all cultivars and years were similar to findings from the by cultivar and year analyses (Fig. 1). Although the Mn treatment by cultivar-year combination interaction $P$ value was 0.0158 , within cultivar and year, the concentration of $\mathrm{Mn}$ in leaf tissue climbed steadily with increasing Mn applications, even though the $\mathrm{P}_{n}$ rates did not climb correspondingly. The design-based analyses indicate optimum $\mathrm{P}_{n}$ rates in the Medium Mn treatment, which had estimated leaf $\mathrm{Mn}$ concentrations ranging from 147.4 (in 2012) to 176.9 (for 'Western' in 2013) $\mu \mathrm{g} \cdot \mathrm{g}^{-1}$; averaging across cultivars and years produced an estimated leaf Mn concentration for the Medium Mn treatment of 158.5 ( $\pm 4.4 \mathrm{SE}) \mu \mathrm{g} \cdot \mathrm{g}^{-1}$ (Fig. 1).

A common cubic polynomial function of leaf $\mathrm{Mn}$ over the range 21.25-472.2 $\mu \mathrm{g} \cdot \mathrm{g}^{-1}$ with separate cultivar intercepts was fitted to $\mathrm{P}_{\mathrm{n}}$ and produced the cubic polynomial equation $y=4.655(\mathrm{Mn} / 100)-2.122$ $(\mathrm{Mn} / 100)^{2}+0.2581(\mathrm{Mn} / 100)^{3}$ with $y$ intercepts 13.66 for 'Pawnee' and 10.94 for 'Western' (Fig. 4). The estimated Mn leaf concentration where $P_{n}$ was highest was at $151.64( \pm 17.3 \mathrm{SE}) \mu \mathrm{g} \cdot \mathrm{g}^{-1} \mathrm{Mn}$; using the outlier strategy did not change this estimate appreciably $\left(154.59 \pm 10.99 \mathrm{SE} \mu \mathrm{g} \cdot \mathrm{g}^{-1}\right)$.

In summary, these data provide strong evidence of improved tree photosynthetic performance in immature nonbearing pecan trees and we predict a similar response in mature, fruit-bearing trees and the possibility of improvement on flowering, fruit set, nut yield, and nut quality with foliar applied $\mathrm{Mn}$ resulting in leaflet $\mathrm{Mn}$ tissue concentrations around $150 \mu \mathrm{g} \cdot \mathrm{g}^{-1}$. Although the Control treatment in our experiment was within deficient levels of leaf tissue Mn concentrations (Heerema, 2013), there were no visible symptoms of Mn deficiency. That pecan is a hyperaccumulator of Mn (Núñez-Moreno, 2009; O'Barr et al., 1987) is evidenced by the fact that visible Mn toxicity symptoms were not apparent in the Ultra-High treatment even though concentrations were above $1000 \mu \mathrm{g} \cdot \mathrm{g}^{-1}$. In addition, the high foliar application rates of $\mathrm{Mn}$ do not confer any additional gas exchange benefit. Nevertheless, $\mathrm{P}_{\mathrm{n}}$ was significantly lower for the Control compared with the Medium treatment and this indicates that pecan trees in the study may have "hidden hunger" for Mn and could benefit from foliar application of Mn. Our data, therefore, confirm a relationship in pecan between $P_{n}$ and $M n$ nutrition and, furthermore, indicate that low $\mathrm{Mn}$ availability may be one factor that limits $P_{n}$ in pecan orchards.

\section{Literature Cited}

Alben, A.O., J.R. Cole, and R.D. Lewis. 1932a Chemical treatment of pecan rosette. Phytopathology 22:595-601.

Alben, A.O., J.R. Cole, and R.D. Lewis. 1932b. New developments in treating pecan rosette with chemicals. Phytopathology 22:979-981.

Anderson, P.C. 1994. Temperate nut species, p. 299-338. In: B. Schaffer and P.C. Anderson (eds.). Handbook of environmental physiology of fruit crops. Vol. 1. Temperate crops. CRC Press, New York, NY.

Barker, A.V. and D.J. Pilbeam. 2015. Handbook of plant nutrition. 2nd ed. CRC Press, Boca Raton, FL.

Brady, N.C. and R.R. Weil. 2007. The nature and properties of soils. 14th ed. Prentice Hall, New Jersey, NJ.

Casella, G. and R.L. Berger. 2002. Statistical inference. 2nd ed. Duxbury, Pacific Grove, CA.

Chang, C.W. 1953. Chemical properties of alkali soils in Mesilla Valley, New Mexico. Soil Sci. 75(3):233-242.

Edwards, D.G. and C.J. Asher. 1982. Tolerance of crop and pasture species to manganese toxicity, p. 145-150. In: Proceedings of the ninth plant nutrition colloquium, Warwick, England. Commonwealth Agricultural Bureau, Farnham Royal, Bucks, UK.

Epstein, E. and A.J. Bloom. 2005. Mineral nutrition of plants: Principles and perspectives. 2nd ed. Sinauer, Sunderland, MA.

Farquhar, G.D. and T.D. Sharkey. 1982. Stomatal conductance and photosynthesis. Annu. Rev. Plant Physiol. 33(1):317-345. 
Gavlak, R.G., D.A. Horneck, and R.O. Miller. 1994. Plant, soil and water reference methods for the western region. Univ. Alaska Western Regional Extension Publ. 125.

Heerema, R.S. 2013. Diagnosing nutrient disorders of New Mexico pecan trees. New Mexico State Univ. Coop. Ext. Guide H-658. 15 Aug. 2013. $<$ http://aces.nmsu.edu/pubs/_h/H658.pdf $>$.

Henriques, F.S. 2003. Gas exchange, chlorophyll $a$ fluorescence kinetics and lipid peroxidation of pecan leaves with varying manganese concentrations. Plant Sci. 165(1):239-244.

Henriques, F.S. 2004. Reduction in chloroplast number accounts for the decrease in the photosynthetic capacity of Mn-deficient pecan leaves. Plant Sci. 166:1051-1055.

Homann, P.H. 1967. Studies on the manganese of the chloroplast. Plant Physiol. 42:997-1007.

Janick, J. and R.E. Paull (eds.). 2008. The encyclopedia of fruit and nuts. CAB International, Cambridge.

Jones, J., Jr., B.W. Benton, and H.A. Mills. 1991. Plant analysis handbook. Macro-Micro Publishing, Athens, GA.

Kriedemann, P.E., R.D. Graham, and J.T. Wiskich. 1985. Photosynthetic dysfunction and in vivo changes in chlorophyll a fluorescence from manganese-deficient wheat leaves. Crop Pasture Sci. 36(2):157-169.

Lindsay, W.L. 1979. Chemical equilibria in soils. John Wiley and Sons Ltd.

Lichtenthaler, H.K. and A.R. Wellburn. 1983. Determinations of total carotenoids and chlorophylls $a$ and $b$ of leaf extracts in different solvents. Proc. Biochemical Soc. Trans. 11: 591-592.

Lombardini, L., H. Restrepo-diaz, and A. Volder. 2009. Photosynthetic light response and epidermal characteristics of sun and shade pecan leaves. J. Amer. Soc. Hort. Sci. 134:372-378.

Marschner, H. 1995. Mineral nutrition of higher plants. 2nd ed. Academic Press, San Diego, CA.

McCaslin, R.D. and L.G. Boyse. 1999. Nutrient status of pecans in the Mesilla Valley. Western Pecan Conference Proc., Las Cruces, New Mexico, 7-9 Mar. 1999. 33:89-94.

Millaleo, R., M. Reyes-Diaz, A.G. Ivanov, M.L. Mora, and M. Alberdi. 2010. Manganese as essential and toxic element for plants: Transport, accumulation and resistance mechanisms. J. Soil Sci. Plant Nutr. 10(4):476-494.

New Mexico State University. 2016. Horticulture publications. New Mexico State University
Board of Regents, Las Cruces. 20 Jan. 2011. $<$ http://aces.nmsu.edu/pubs/_h/\#nuts $>$.

NRCS. 2014. USDA Natural Resources Conservation Service Web Soil Survey, Washington, DC. 15 Jan. 2014. <http://websoilsurvey.sc. egov.usda.gov/App/WebSoilSurvey.aspx>.

Núñez-Moreno, J.H. 2009. Nutritional studies on pecans [Carya illinoinensis L. (Wangenh.) C. Koch] growing in irrigated alkaline soils. Univ. Arizona, Tucson PhD Diss. Abstr. b6848490.

O'Barr, R.D., S. Rachal, K. Koonce, and J. Kowalzuk. 1987. Influence of manganese applications on nine elements in pecan leaves, trunk and roots. Louisiana Agr. Expt. Sta. Circular 102-112.

Ohki, K. 1985. Manganese deficiency and toxicity effects on photosynthesis, chlorophyll and transpiration in wheat. Crop Sci. 25:187-191.

Othman, Y., D. VanLeeuwen, R. Heerema, and R.S. Hilaire. 2014. Midday stem water potential values needed to maintain photosynthesis and leaf gas exchange established for pecan. J. Amer. Soc. Hort. Sci. 139:537-546.

Piepho, H.P., E.R. Williams, and M. Fleck. 2006. A note on the analysis of designed experiments with complex treatment structure. HortScience 41:446-452.

Pond, A.P., J.L. Walworth, M.W. Kilby, R.D. Gibson, R.E. Call, and J.H. Núñez-Moreno. 2006. Leaf nutrient levels for pecans. HortScience 41:1339-1341.

Ramsey, F.L. and D.W. Schafer. 2002. Statistical sleuth: A course in methods of data analysis, 2nd ed. Duxbury Press, Pacific Grove, CA.

Robinson, J.B., M. Treeby, and R.A. Stephenson. 1997. Fruits, vines, and nuts, p. 347-382. In: D.J. Reuter and J.B. Robinson (eds.). Plant analysis, an interpretation manual. CSIRO Publishing, Collingwood, Victoria, Australia.

Rule, J.H. and E.R. Graham. 1976. Soil labile pools of manganese, iron, and zinc as measured by plant uptake and DTPA equilibrium. Soil Sci. Soc. Amer. J. 40:853-857.

Sims, J.T. 1986. Soil $\mathrm{pH}$ effects on the distribution and plant availability of manganese, copper, and zinc. J. Soil Sci. Soc. Amer. 50:367-373.

Smith, M.W., B.S. Cheary, and B.S. Landgraf. 2001. Manganese deficiency in pecan. HortScience 36:1075-1076.

Smith, M.W. and B.C. Cotton. 1985. Relationship of leaf elemental concentrations and yield to cold damage of 'Western' pecan. HortScience $20: 420-422$.
Sparks, D. 2000. Temperate fruit crops in warm climates: Pecan in warm climate. Springer, The Netherlands.

Sparks, D. 2002. Rainfall governs pecan stand homogeneity in native, wild habitats. J. Amer. Soc. Hort. Sci. 127:860-868.

Sparks, D. 2005. Adaptability of pecan as a species. HortScience 40:1175-1189.

Spencer, D. and J.V. Possingham. 1960. The effect of nutrient deficiencies on the Hill reaction of isolated chloroplasts from tomato. Austral. J. Biol. Sci. 13(4):441-455.

Spencer, D. and J.V. Possingham. 1961. The effect of manganese deficiency on photophosphorylation and the oxygen-evolving sequence in spinach. Biochim. Biophys. Acta 52(2):379-381.

Terry, N. and A. Ulrich. 1974. Photosynthetic and respiratory $\mathrm{CO}_{2}$ exchange of sugar beet as influenced by manganese deficiency. Crop Sci. 14(4):502-504.

Thompson, T.E. and L.J. Grauke. 1991. Pecans and other Hickories (Carya). Acta Hort. 290:839-906.

U.S. Environmental Protection Agency. 1982. Inductively coupled plasma atomic emission spectrometric method for trace element analysis of water and wastes. U.S. Environ. Protection Agency, Washington, DC.

USDA, National Agricultural Statistics Service. 2015. Noncitrus fruits and nuts. 20 July 2015 $<$ http:/usda.mannlib.cornell.edu/usda/current/ NoncFruiNu/NoncFruiNu-07-17-2015.pdf $>$.

Walworth, J.L. and A.P. Pond. 2006. Zinc nutrition of pecans growing in alkaline soil. Pecan South 39:14-22.

Walworth, J.L., A.P. Pond, and M.W. Kilby. 2011. Leaf sampling guide with interpretation for Arizona pecan orchards. University of Arizona College of Agriculture and Life Sciences, Cooperative Extension, Bul. AZ1410. 15 July 2012. <http://extension.arizona.edu/sites/ extension.arizona.edu/files/pubs/az1410.pdf $>$.

Weiland, T., R.D. Noble, and R.E. Crang. 1975. Photosynthetic and chloroplast ultrastructural consequences of manganese deficiency in soybean. Amer. J. Bot. 62(5):501-508.

Worley, R.E. 1994. Pecan nutrition, p. 1995-2003. In: Sustaining pecan productivity in the $21 \mathrm{st}$ century. 2nd National Pecan Workshop Proc. Wagoner, OK.

Zhang, X., E.H. Ervin, and R.E. Schmidt. 2005. The Role of leaf pigment and antioxidant levels in UV-B resistance of dark- and light-green kentucky bluegrass cultivars. J. Amer. Soc. Hort. Sci. 130:836-841. 